\title{
Swear Words Translation in The Raid Movie and Its Classification
}

\author{
Evandio Zefanya Pattiselanno
}

English Department, Faculty of Languages and Literature, Petra Christian University, Siwalankerto 121131, Surabaya 60236, INDONESIA

E-mail: m11415005@john.petra.ac.id

\begin{abstract}
This study wanted to help the reader to understand about the classification of swear words in "The Raid" movie's dialogue. The writer used Larson's (1984) kinds of translation (literal and idiomatic translation). The writer was interested in analyzing the swear words, especially the classification of translation whether it match to the original meaning or not, for example "anjing" becomes "dog", "bajingan" becomes "bastard" or being translated using different swear words in the English subtitle of the movie. The writer found that there are so many dialogues translated using swear words on the subtitle of the movie while the dialogue itself does not have any swear words. The rest of other swear words are being translated match with its original meaning, and there are also different translation.
\end{abstract}

Keywords: translation, swear word, subtitle, literal translation, idiomatic translation

\section{INTRODUCTION}

In this study, I would like to analyze the Indonesian swear words translation in the Indonesian movie titled "The Raid". This film is about police team that wanted to kill an Indonesian mafia boss who had so much subordinates (gang members) to protect him. There are so many swear words in the dialogue for example "anjing", "bangsat", "kampret" and so on. These words are being used in the dialogue to describe bad situation while there are fighting with their enemy, and insult their enemies when they are angry. The subtitle had translated most of the dialogues, including the Indonesian swear words into English. The purpose of this study is to find out about the classification of the translation of swear words in "The Raid" film, also to find out what dialogue that have been translated using swear words while the original dialogue did not have any swear words at all, and then categorize it whether it is swearing or emphatic.

The main theory that I used are literal translation, and idiomatic translation by Larson (1984). He stated that an interlinear translation is completely a literal translation. For some purposes, it is needed to reproduce the linguistic features of the source text, for example, in a linguistic study of a language. Idiomatic translations use the natural forms of the receptor language, both in the grammatical constructions and in the choice of lexical items. A truly idiomatic translation does not sound like a translation. It sounds like it was written originally in the receptor language.

Larson (1984: 3) in his book Meaning Based Translation: A Guide to Cross-Language Equivalence, translation, by dictionary definition, consist of changing from one state or form to another, to turn into one's own or another language. He also stated in his book (1984) that literal translation means form based translation that always follow the original source's context. Meaning based translation make every effort to communicate the meaning of the source language text in the natural forms of the receptor language. This is called idiomatic translation.

The second thing is about subtitle. Shuttleworth and Cowie (1997: 161) in their book entitled Dictionary of Translation Studies states that subtitling is the process of giving a caption (writing 
below the screen) that has been synchronized in dialogue in shows in films, television and opera that are broadcast live.

According to Winiasih (2010), there are some types of swear word, those are: Circumstances, Animals, Scary Creatures, Objects, Body Parts, Kinship, Activities, Profession, Food, and Place. Based on these types, I thought that all of the swear words in the movie can be divided into some type related into Winiasih's type.

\section{METHOD}

This study was a descriptive qualitative research. I analyzed the data to describe about types of Indonesian swear words which are being translated in the same classification or not, from Indonesian to English from "The Raid" movie. Next thing, Indonesian dialogue in "The Raid" movie that being translated into English using swear words and find out whether it is categorized as swearing or not swearing.

The instrument of the study was the writer himself. I was the one who collected and analyzed the data. First, I watched the movie by himself, and then I re-watched it to collect the swear words translation based on the minute it appears. After that, I looked on every swear words that he collected, and then gave explanation on the table about the type of the swear words, those are same form, different form, and Indonesian dialogue translated using swear words. After collecting the data, I realized that there is some part on the third category that could also be classified as emphatic, so the writer had made part into two, those are dialogue translated into swearing, and dialogue translated as emphatic simply by just adding a column "translation type" to describe whether it is swearing or emphatic. The source of data of this study were English subtitles taken from Indonesian movie called "The Raid". I took the subtitles from every bad situation in the movie, those are the moments when actors are insulting someone, fighting with their enemies, asking another character to do something, and so on. The subtitles were taken from the utterances expressed by some characters named Sgt. Jaka (leader of the police team), Lieutenant Wahyu, the other police member, the gangsters (including Andi and Mad Dog), and Tama (leader of the gangsters).

The data I collected is the English subtitle of the swear word. I analyzed all translation of the swear word using theory of literal and idiomatic translation by Larson (1984). I wanted to know whether the Indonesian swear word are being translated into the same form, or different form. There are also dialogues translated into English using swear word, so I looked the Indonesian meaning of the English swear word itself from KBBI, and then tried to find out about the closest meaning of it.

I divided all of the swear words into three categories, those are same form translation, different form translation, and dialogue translated using swear words. The next thing, I gave code to every classification type, 1 for same classification, 2 for different classification, and 3 for dialogue translated using swear words. I realized that there are some swear words on the $3^{\text {rd }}$ category that could be put into emphatic, so I changed the table a little bit different from $1^{\text {st }}$ and $2^{\text {nd }}$ category simply by just adding a column "translation type" to describe whether it is swearing or emphatic and gave some explanation about it.

\section{FINDINGS AND DISCUSSION}

I analyzed the data that he got by watching the movie from the beginning until the end, collected all data based on the minute it appears, and then divided all of it into some classification. I used the translation theory by Larson (1984). 
I divided all swear words into three categories, those are same form translation, different form translation, and dialogue translated using swear words. I gave code to every classification type, 1 for same classification, 2 for different classification, and 3 for dialogue translated using swear words. I also gave note on every swear words to describe about the situation when the swear words appear on the movie, and then give some explanations below the table on every category. I realized that there are some swear words on the $3^{\text {rd }}$ category that could be put into emphatic, so I changed the table a little bit different from $1^{\text {st }}$ and $2^{\text {nd }}$ category simply by just adding a column "translation type" to describe whether it is swearing or emphatic and then give some explanation about it.

\section{The Same Form Translation}

In this part, the Indonesian swear words translated match as it's literal meaning in English. That means, those dialogues showed that a character wanted to insult another character who was talking with him. Usually, these utterances appeared during fighting scenes, and arguing. For example, "Kalian semua brengsek" became "You guys are jerk". The man was trying to explain that he did not have anything suspicious in his room with anger to the gang member, but suddenly he also insulted them. The writer thought that "Lu gila ya?" is included in this part since it being translated as "Are you out of your fucking mind?". The literal meaning of gila itself is crazy, but it could be also matched with out of your mind, and the subtitle just added "fucking." As I told above, this part used literal translation by Larson. All of the Indonesian swear words had been translated into English without changing any context at all. Even the subtitle translation has the same grammatical form with the Indonesian dialogue.

There is also one swear word in this category that used Idiomatic translation. Although the grammatical form is not exactly the same, but it still has the same meaning, for example: "Persetan dengan pangkat" became "I don't care with my fucking rank". 'Persetan' in KBBI means does not care, but since the context is rude, the translation added 'fucking'. Sgt Jaka did not want to comply to Lieutenant Wahyu's order although his rank is lower.

Winiasih theory that could be related into this type are activities (bangsat which means someone who wanted to do bad things), circumstances (tolol which means about someone's psychologycal situation who could not understand about something easily, gila which means absurd, does not make sense, persetan which means does not care about the situation, brengsek means chaotic situation), profession (bajingan which means someone works as criminal).

\section{Different Form Translation}

There are so many swear words translated into English using fuck in this category. The literal meaning of fuck itself is bersetubuh, but it can also be used to insult somebody. For example, "Babi lo" became "Well fuck you too". Another example, "Enggak, kampret." became "No, you son of a bitch". This is a different meaning since the definition of kampret itself is kelelawar. However, the context itself was not about bat but it was insulting, that is why it became "son of a bitch". There is also "Dengar bangsat" became "Listen up, asshole". The literal meaning of "asshole" itself is lubang pantat. The writer thought it should be translated as "Listen up, bastard". Another example, "Cuman monitor ini doang yang bisa gua pegang kayaknya, njing" became "Looks like I can only trust this monitor, asshole". The writer thought that it would not make sense if this dialogue being translated "Looks like I can only trust this monitor, dog". It would be better if "njing" being translated using "fuck" or "asshole", to show an anger of somebody while insulting. All swear word translation on this category used idiomatic translation. Although the grammatical form is not exactly the same, but it still has the same meaning with the Indonesian dialogue and swear words after it being translated in the English subtitle. 
I thought that literal translation could not be used in this category because the meaning of the swear words after being translated into English would not make sense. For example: "Babi lo" will become "Pig you", "Enggak, kampret" will become "No, bat", "Cuman monitor ini doang yang bisa gua pegang kayaknya, njing." will become "Only this monitor that I can touch maybe, dog.".

Winiasih theory that could be related into this type are activities changed into body part (bangsat which means someone who wanted to do bad things become asshole means lubang pantat), animals changed into body part (anjing which means dog become asshole means lubang pantat), animals changed into activities (babi which means pig become fuck means bersetubuh), animals changed into profession (kampret kelelawar become son of a bitch means bajingan).

\section{Dialogue translated using swear words}

All of the dialogue had no swear words on the Indonesian dialogue, but translated into English using swear words. Most of the translation used "fuck". The writer thought that it used "fuck" to describe about bad situation, to describe about someone's anger, to insult someone, and many more in a very rude way. For example, "Ini bukan tempat latihan" became 'This is not a fuckin' field training you know", where Lieutenant Wahyu warned Jaka about the situation they were facing. Another example: "Gua cuma butuh satu peluru untuk nembak batok kepala lo" became "I just need one bullet to blow your fucking head". Lieutenant Wahyu threatened Tama to kill him if he wanted to do so with anger. These examples are categorized as swearing.

There is "Kamu mau saya cincang istrimu hah?" translated "You want me to slice that bitch up? ". The writer thought that the gang member threatened the man to kill his wife if he did not want to shut up. The gang member said that with anger, so the man would not mess with him.

The following examples are the examples of emphatic function. Rama said "Gua ngomong gini karena elo abang gua" became "I'm telling you this, because you are my fucking brother", Andi said "Lu milih tinggal disini, lu umpanin nyawa lo" became "If you stay here, you'll be fucking dead before that boy is born". Rama and Andi were cared to each other because they did not want either one of them died. Another example of emphatic dialogues are: "Sekarang, bawa saya keluar" translated "Now you're going to get me the fuck outta here.", "Keluarin gue darisini!" translated "Get me the fuck out of here!". All of these dialogues are categorized as emphatic. Emphatic in the movie's dialogue context means showing love to each other by helping someone or advising someone to take care. Although the grammatical form in English using swear word, it does not mean rude.

This translation category uses both literal translation and idiomatic translation. Example of literal translation are: "Gua cuma butuh 1 peluru untuk nembak batok kepala lo" became "I just need one bullet to blow your fucking head", "Diam, angkat tanganmu!" became "Shut the fuck up! Hands up", "Elo buang buang waktu, lo" became "You did waste my fucking time", "Gua ngomong gini karena elo abang gua" became "I' $m$ telling you this, because you are my fucking brother", "Siapa tuh?" became "Who the fuck is this?", etc.

Example of Idiomatic translation are: "Kita tetap satu barisan, lebih waspada" became "Find out what the fuck is going on out there", "Kamu kelautpun saya tidak peduli" became "I don't give a shit where you need to go", "Jangan coba-coba kau tipu saya, he" became "Don't fucking question me my friend.". 


\section{CONCLUSION}

This study shows about the classification of swear words in "The Raid" movie, specifically from Indonesian into English. There are a lot of swear words occurred in the movie, for example "bangsat", "anjing", "kampret" and so on. These swear words usually uttered to describe about bad situation, insulting someone, and so on.

I found out that all of the swear words translation had been translated into the true rendering and different rendering, so I divided the swear words into some categories, those are same form classification, different form classification, and dialogue translated using swear words.

Same form translation, means that the Indonesian swear words are being translated into true rendering, for example "Kalian semua brengsek", became "You guys are jerk" , "Persetan dengan pangkat" became "I don't care with my fucking rank", "Lu gila ya?" became "Are you out of your fucking mind?" All of the Indonesian swear words had been translated into English without changing any context at all. Even the subtitle translation has the same grammatical form with the Indonesian dialogue.

Different form translation, means that the grammatical form of the translation is not exactly the same, but it still has the same meaning with the Indonesian dialogue and swear words after it being translated in the English subtitle. For example, "Enggak, kampret." became "No, you son of a bitch". This is a different translation form since the definition of kampret itself according to KBBI is kelelawar. However, the context itself was not about "bat" but it was insulting, that is why it became son of a bitch.

The third one is dialogue translated using swear words. This category has no swear word in the Indonesian dialogue of the movie, but it been translated into English using swear word. The writer made a little change simply by just adding a column "translation type" to describe whether it is included as swearing or emphatic. For example: "Ini bukan tempat latihan" became "This is not a fuckin' field training you know", where Lieutenant Wahyu warned Jaka about the situation they were facing. Another example: "Gua cuma butuh satu peluru untuk nembak batok kepala lo" became "I just need one bullet to blow your fucking head". Lieutenant Wahyu threatened Tama to kill him if he wanted to do so with anger. These examples are categorized as swearing.

Another examples, "Gua ngomong gini karena elo abang gua" became "I'm telling you this, because you are my fucking brother", "Lu milih tinggal disini, lu umpanin nyawa lo" became "If you stay here, you'll be fucking dead before that boy is born". Rama and Andi were cared to each other because they did not want either one of them died. These two dialogues are categorized as emphatic.

The writer thought that the emphatic type can be related to Basa Suroboyoan by Winiasih. It can be used to show solidarity between friends, families, relatives, and so on. Although it may contain swear words, but it does not mean rude.

\section{REFERENCES}

Cowie, S. (1997). Dictionary of Translation Studies. St. Jerome Publishing.

Larson, M. L. (1984). Meaning Based Translation: A Guide to Cross- Language Equivalence. New York: University Press of America, Inc.

Nasional, P. B. (2008). Kamus Bahasa Indonesia. Jakarta: Pusat Bahasa Departemen Pendidikan Nasional. 
Prasetyo, A. (2018, April 13). Pengertian dan Contoh Makian dalam Sosiolinguistik. Retrieved from linguistikid.com: https://www.linguistikid.com/2018/04/pengertian-dan-contohmakian-dalam.html

Samsidi, A. H. (2009). The Misleading translation mistakes of indonesian subtitles in the movie love actually. Surabaya: Universitas Kristen Petra. Retrieved from dewey.petra.ac.id.

Saputra, E. (2015, June 25). Sinopsis Film "The Raid: Redemption". Retrieved from https://www.kompasiana.com/:

https://www.kompasiana.com/www.cheat.web.id/550ed497813311b62dbc64ef/sinopsis -film-the-raid-redemption

Winiasih, T. (2010). PISUHAN DALAM “BASA SUROBOYOAN”. Retrieved from core.ac.uk: https://core.ac.uk/download/pdf/12352342.pdf 